\title{
Seasonal sediment transport pathways in Lirquen Harbor, Chile, as inferred from grain-size trends
}

\author{
Felipe Ríos $^{1 *}$, Marco Cisternas ${ }^{2}$, Jacobus Le Roux ${ }^{3}$ y Iran Corrêa ${ }^{4}$ \\ ${ }^{1}$ Departamento de Oceanografía, Universidad de Concepción, Casilla 160-C, Concepción, Chile \\ E-mail: fel66_ni@yahoo.com \\ ${ }^{2}$ Centro EULA-Chile, Universidad de Concepción, Casilla 160-C, Concepción, Chile \\ E-mail: mcisterv@udec.cl \\ ${ }^{3}$ Departamento de Geología, Facultad de Ciencias Físicas y Matemáticas, Universidad de Chile, \\ Casilla 13518, Correo 21, Santiago, Chile. E-mail: jroux@cec.uchile.cl \\ ${ }^{4}$ Centro de Estudos de Geologia Costeira e Oceânica, Universidade Federal do Rio Grande do Sul, \\ Brasil. E-mail: iran.correa@ufrgs.br
}

Recibido: 20 mayo 2000; versión corregida: 8 marzo 2002; aceptado: 20 marzo 2002

\begin{abstract}
Bottom sediment samples were collected in June and December 1997 at 166 stations on a rectangular grid in a small port (Lirquén Harbor, BíoBío Region, Central Southern Chile) facing siltation problems with a view to determining local seasonal sediment transport pathways through the application of three different methodologies based on grain-size trends. Measured winds and near-bottom currents together with hindcast wave allowed to establishing the influence of the prevailing meteorological and hydrodynamic conditions on local sediment circulation. The results suggest that transport of deep and shallow water sediments occur rarely under high-energy conditions. The current data suggest that tidal asymmetry would be an important agent of sediment transport in Lirquen Harbor.

The sediment transport pathways inferred from grain-size trends are compared with the measured water circulation of the study area and sediment dispersal patterns on aerial photographs. The results yielded by the grain-size trend methodologies of Gao-Collins (1992) and Le Roux (1994b) indicate a possible seasonal variation in transport pathways agreeing with the prevailing meteo-hydrodynamic conditions, whereas the McLaren-Bowles (1985) approach does not show a significant difference. It is suggested that the latter methodology may represent transport on a spatial macroscale as opposed to the mesoscale patterns yielded by the other two techniques. Based on the results of the three grain-size trend methodologies, the observed current and wind data, the hindcast wave data and aerial photographs a conceptual model of net annual sediment transport is proposed for Lirquén Harbour.
\end{abstract}

Keywords: sediment transport pathways, grain-size trends, Lirquén Harbor, southern Chile.

\section{Patrones estacionales de transporte de sedimentos en puerto Lirquén, Chile, inferidos mediante el análisis de las tendencias granulométricas}

RESUMEN. En junio y diciembre de 1997 se realizaron dos campañas de muestreo sedimentológico en un puerto afectado por el embancamiento (Puerto Lirquén, Región del Biobío, Chile) con el fin de determinar la circulación sedimentaria del área de estudio a través de la aplicación de tres metodologías basadas en el análisis de los cambios espaciales de los parámetros granulométricos de los sedimentos. Se estudia la relación entre los regímenes meteorológicos-oceanográficos y de transporte de sedimentos, los resultados de este análisis indican que la movilidad de los sedimentos está asociada a los eventos altamente energéticos que afectan a la Región.

Los patrones de transporte obtenidos mediante las metodologías de McLaren-Bowles (1985), Gao-Collins (1992) y Le Roux (1994b), se comparan con el patrón residual de circulación de las aguas y con fotografías aéreas del área de estudio. Los resultados mostrados por las dos últimas metodologías reconocen una variación estacional en el patrón de transporte de sedimentos, concordando así con la variabilidad estacional de las condiciones meteorológicas y hidrodinámicas prevalecientes. Por lo tanto, se sugiere que los patrones de transporte obtenidos a través de las metodologías de Gao-Collins y Le Roux estarían representando la circulación de sedimentos a una mesoescala espacial. Sobre la base de los patrones de transporte de sedimentos inferidos, los datos analizados de viento, corrientes y oleaje en conjunto con fotografías aéreas se propone para Puerto Lirquén un modelo conceptual de transporte neto anual de sedimentos.

Palabras claves: patrones estacionales de transporte de sedimentos, análisis de tendencias granulométricas, Puerto Lirquén, sur de Chile.

* Present address: Antumapu 6856, La Florida, Santiago, Chile. 


\section{INTRODUCTION}

Over the last two decades there has been a rapid development of methods employed to identify net sediment transport paths in coastal marine environments (McLaren, 1981; McLaren and Bowles, 1985; Gao and Collins, 1992, 1994; Le Roux, 1994b). All of these techniques are based upon spatial changes (trends) in the grain-size parameters of bottom sediments, which result from sediment transport processes.

Between 1930 and 1980, attempts were made to relate the variation of one single grain-size parameter to sediment transport paths (Pettijohn and Ridge, 1932; Pettijohn et al., 1972; McCave, 1978), but this approach did not always produce good results since grain-size parameters are sensitive to different sedimentary environments (Friedman, 1979). More recent studies showed that a combination of three grain-size parameters (mean size, sorting and skewness) produces better results (McLaren, 1981; McLaren and Bowles, 1985). The "McLaren Model" determines the transport direction along a sampling track by comparing the sedimentological parameters of all possible pairs of samples on the sampling line, resulting in a one-dimensional sediment transport model. This model has been tested in many natural environments by different authors, obtaining results that agree with their interpretation of sediment transport in these environments (McLaren and Little, 1987; McLaren et al., 1993). Nevertheless, some authors have questioned the universal applicability of the model, suggesting that its use is limited to certain specific environments (Masselink, 1992).

Gao and Collins (1991) suggested modifications to the original approach of McLaren and Bowles (1985), proposing a two-dimensional model for the analysis and introducing the concept of transport vectors into the grain-size trend analysis. This new technique differs from the previous methods in that it defines a grid of dimensionless trend vectors by comparing the grain-size parameters of "neighboring" stations, which are later transformed into transport vectors by applying a filtering technique. According to Gao and Collins (1991, 1992), the implementation of the vector approach produces more meaningful results and reduces the implied "bias" in the selection of the sampling lines inherent in the line-by-line approach of McLaren and Bowles (1985). The potential of this methodology is supported by its successful application in different coastal environments (Gao et al., 1994; Pedreros et al., 1996).

The main shortcoming of this procedure is that only two sampling sites are compared at a time, which does not allow for the fact that sediment transport probably takes place within zones and not from point-to-point. Thus the relative location of any two stations within a transport zone will determine the resultant vector. Another problem lies in the fact that the Gao and Collins method assigns a vector of unit length between all sampling points, which obscures the significance of the vector magnitude obtained by subsequent filtering. The method thus has a low probability of determining the true transport directions (Le Roux, 1994a).

In an attempt to circumvent these problems, Le Roux (1994b) proposed an entirely different approach based on conventional vector analysis. In this method, trend vectors are obtained by comparing groups of five stations (one central and four satellites) at a time and the grain-size parameters are integrated so that each assumes equal status. Finally, only those overall patterns produced by trend types or combinations of trend types with a vector magnitude exceeding a value determined by the nonparametric Watson test are accepted (Le Roux et al., in press). Presently, only a few authors have tested the real-world validity of this model (Carriquiry and Sánchez, 1999).

Over the last two decades, Lirquén Harbor has experienced the effects of continuous siltation at its mooring sites, necessitating frequent and costly dredging operations with an average of $30.000 \mathrm{~m}^{3}$ of sediments having to be removed periodically. As this has to be done without the benefit of knowing the existing sediment transport regime, the main object of this investigation was to determine the sediment circulation pattern and the location of depocenters within the harbor by comparing the sediment transport patterns obtained through the methodologies of McLaren and Bowles (1985), Gao and Collins (1992) and Le Roux (1994b).

To obtain additional information on possible seasonal variations in the transport patterns, two sets of samples were taken at the same stations during June (winter) and December (summer) 1997. There is some uncertainty as to whether a 5 month time interval would allow a real change in sediment circulation to be manifested, which is exacerbated by the use of a grab sampler collecting a disturbed sample possibly representing a longer period of time than individual seasons. However, estimates based 
on the volume of sediments dredged over the period from 1985 to 1996 from the mooring sites, indicate a depositional rate of up to $21 \mathrm{~cm}$ per year. The obtained grain-size trends may thus well represent transport on a seasonal scale.

To test the validity of this concept, the results of the analyses are compared with current measurements obtained during the period of sampling, as well as known sediment distribution patterns as observed on aerial photographs of the study area. An analysis is also undertaken to evaluate the influence of windinduced waves and the interaction of bottom currents and waves on the direction of local sediment transport. Lastly, the grain-size trend methodologies are discussed on the basis of their applicability as predictive tools in understanding the natural sedimentary processes of this harbor.

\section{Study area}

Lirquén Harbor, located within the southeastern part of Concepción Bay (36 $\left.40^{\prime} S ; 73^{\circ} 02^{\prime} \mathrm{W}\right)$ Chile, has two pile-supported piers with six mooring sites. Due to its infrastructure and depth, it is one of the most important commercial ports in Chile (Fig. 1). Concepción Bay is a shallow (maximum depth about $48 \mathrm{~m}$ ) coastal embayment located on the southeastern Pacific coast of Chile. It is characterized by an almost rectangular shape with a gentle slope increasing toward the north, where it is connected with the Pacific Ocean. The bay has a surface area and water volume of $190 \mathrm{~km}^{2}$ and $2.4 \times 10^{9} \mathrm{~m}^{3}$, respectively.

The climate of the area is influenced by anticyclonic winds associated with a high-pressure cell
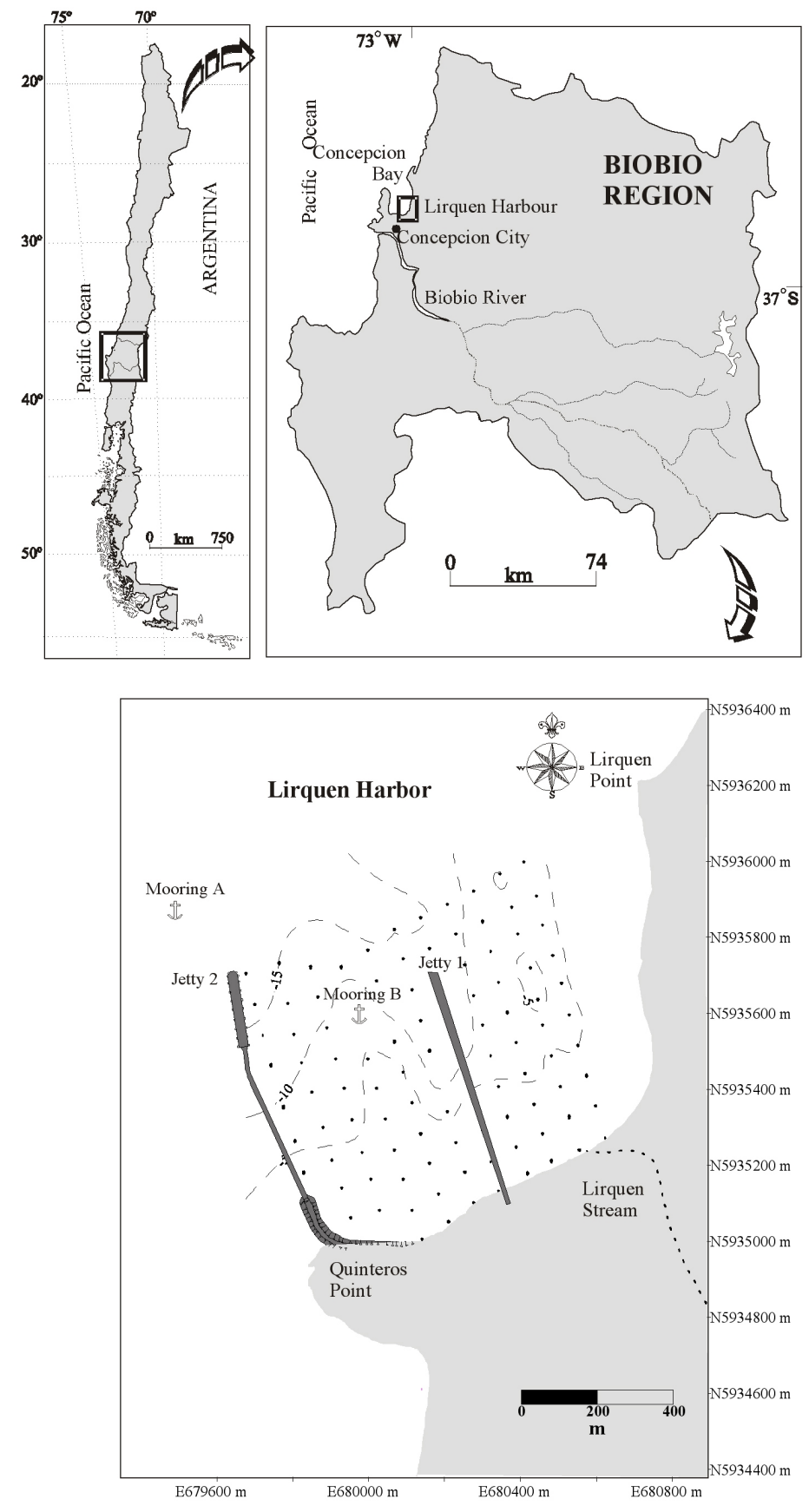

Figure 1. Location map of the Lirquen Harbor study area. Dots represent sampling grid. Moorings A and B are the locations of current meters. Bathymetry is in meters.

Figura 1. Mapa de ubicación del área de estudio. Los puntos representan la ubicación de las estaciones de muestreo sedimentológico. Los Anclajes A y B representan la ubicación de los correntómetros desplegados. Las líneas discontinuas indican la batimetría del área en metros. 
centered in the South Pacific Ocean. During the austral winter, strong, consistently northerly winds with a mean speed of $12.86 \mathrm{~m} / \mathrm{s}$ prevail, whereas summer winds are predominantly southwesterly with lower speeds $(9.78 \mathrm{~m} / \mathrm{s})$ and more variable directions (Saavedra, 1980).

Concepción Bay has semi-diurnal tides within a microtidal range. The oceanography of the region is influenced by the surface Humboldt Current, which is sub-Antarctic in origin and flows northward along the coast. Below this surface water the equatorial subsurface water mass flows southward. Within Concepción Bay itself, the sub-Antarctic surface flow prevails during late fall to early spring, whereas the equatorial subsurface flow dominates between late spring and early fall (Ahumada and Chuecas, 1979). The maximum significant wave height $(1.6 \mathrm{~m})$ occurs in winter, when waves from north-northwesterly directions and a mean period of $4.8 \mathrm{~s}$ predominate. Due to its sheltered nature, the bay is largely protected from west-southwesterly waves (CICLO, 1992).

Current measurements in the eastern part of Concepción Bay showed patterns that vary with seasonal changes (Sobarzo et al., 1997). During winter, northerly winds carry surface water into the bay, causing a compensating bottom flow out to sea. In summer, winds from the southwest cause an outgoing layer on surface and a circulation layer entering the bay near the bottom. The circulation in Concepción Bay is tide-dominated; winds and meteorological effects make secondary contributions (Sobarzo, 1993).

The littoral zone is composed of a Paleozoic basement of crystalline rocks, granites and shales partly covered by sedimentary rocks from the CretaceousTertiary Periods (Aguirre et al., 1972). The bottom sediments of Concepción Bay are dominated by black, organic-rich muds covering a large part of the area. The sediments along the coast are sandy, deriving from rocky outcrops and erosion of the continent. Experiments conducted along the coast of Lirquén Harbor using natural minerals as tracer materials identified a net southward sediment transport direction (EULA, 1994).

\section{MATERIALS AND METHODS}

\section{Sampling Procedures}

During June and December 1997, a total of 166 bottom sediment samples were collected on a grid with an average spacing of $80 \mathrm{~m}$ between each sampling station (Fig. 1), using a Petit-Ponar grab sampler $\left(225 \mathrm{~cm}^{2}\right)$. A sub-sample of the top $10 \mathrm{~cm}$ of each grab was used to analyze the grain-size distributions. The positioning of the sampling stations was determined with a Differential Global Positioning System (DGPS).

To evaluate their potential effect on net sediment movement, winds, mean currents and waves were investigated during winter and summer conditions. Directions and velocities of near-bottom currents were determined by two current meter moorings deployed in the study area for a period of 8 days during June and December 1997 (Fig. 1). During June moorings A and B were deployed in mean water depth of 20 and $9 \mathrm{~m}$, respectively. At mooring A current was measured at $15 \mathrm{~m}$ depth, while at mooring B the current was recorded at $6 \mathrm{~m}$ depth. In December 1997 moorings A and B were deployed in 17 and $8.5 \mathrm{~m}$ depth, respectively. There was a current meter at $16 \mathrm{~m}$ depth at site $\mathrm{A}$, while at site B the current was measured at $7 \mathrm{~m}$ depth. The SensorData 6000 current meters were programmed for a 10 minute sample frequency. Wind data for the period of current meter deployments were collected every 10 minutes at $10 \mathrm{~m}$ height from a coastal weather station at the Hualpen Peninsula in Talcahuano. Since waves were not measured during this investigation, wave heights, periods and directions were determined from wave hindcasting using the computer model NARFET developed by the Costal Engineering Research Center of the U.S. Army Corps of Engineers (Smith, 1991). This model was formulated specifically for wave generation on bodies of water where fetches are short $(<120 \mathrm{~km})$. The effective fetch was calculated according to Saville (1954).

\section{Analytical Procedures}

\section{Sedimentological data}

Separation of the samples into their textural fractions (gravel, sand and mud) was accomplished through wet sieving using standard sieves of -1 and 4 phi. The gravel and sand fractions were oven-dried and weighed to determine their relative percentages (Lewis, 1984). The coarse fraction was analyzed with a digital settling tube (Syvitski et al., 1991), providing the frequency distribution of equivalent particle diameters at intervals of 0.5 phi. The analysis of the mud fraction was carried out with an 
Electrozone system using apertures of 48 and 120 microns over intervals of 0.5 phi. The grain-size data obtained with these two instruments were merged to obtain complete grain size distributions. The method of moments (McManus, 1988) was used to obtain the statistical size parameters (mean, $\mu$; sorting coefficient, $\sigma^{2}$; and skewness, $\mathrm{Sk}$ ).

The grain size data are expressed in the logarithmic phi $\left(\phi=-\log _{2}\right.$ diameter in $\left.\mathrm{mm}\right)$ scale which in comparison with the linear scale, provides better statistical measures for the determination of sediment transport directions (McLaren and Bowles, 1985).

\section{Current, wind and wave data}

The current and wind time series were graphically presented and their basic statistics were computed. Prior to this analysis, the orthogonal components $(\mathrm{u}, \mathrm{v})$ of current and wind velocity were aligned with true north. For coordinate axes the right-handed system described by Pond and Pickard (1978) was used where $u$ is positive to the east and $v$ is positive to the north. As the most important source of bed agitation on the shoreface zone are oscillatory flows associated with surface gravity waves, the threshold for sediment movement under oscillatory waves was calculated using the equation developed by Komar and Miller (1975). This equation relates the sediment size to the wave orbital velocity and orbital diameter through:

$$
\frac{\rho u_{t}^{2}}{\left(\rho_{s}-\rho\right) g D}=0.21\left(d_{0} / D\right)^{1 / 2}, D<0.5 m m
$$

where $\rho_{s}$ is the sediment density, $\rho$ is the water density, $u_{t}$ is the near-bottom threshold orbital velocity, $g$ is the gravitational acceleration, $\mathrm{D}$ is the mean diameter of the sediment grains and $d_{0}$ is the wave orbital diameter calculated from the estimated wave parameters (wave height and period) according to linear Airy-wave theory.

The threshold for sediment movement under combined waves and currents and the direction of the resulting sediment transport were calculated at those depths where wave-orbital motions were insufficient to resuspend sediments by themselves using a one-dimensional numerical model for combined flow conditions (SEDTRANS96) developed by Li and Amos (2001). This model provides solutions for the combined flow shear velocity $\left(\mathrm{u}_{*_{\mathrm{cw}}}\right)$ based on Grant and Madsen (1986) combined flow boundary layer theory. When current velocity was measured at a height other than $1 \mathrm{~m}$ above the bottom, $u_{100}$ (mean velocity at $1 \mathrm{~m}$ above the bottom) was obtained from a logarithmic profile. Data of wave, current and seabed parameters are required to run the model. A detailed description of this model is given in Li and Amos (2001).

\section{Sediment transport patterns by grain size trend analysis}

The grain size parameters were used to determine the existing sediment transport patterns in Lirquén Harbor through the application of the three methodologies discussed in this paper (McLaren and Bowles, 1985; Gao and Collins, 1992; Le Roux, 1994b).

The McLaren and Bowles (1985) methodology determines the net sediment transport direction comparing the sedimentological parameters (mean, sorting coefficient and skewness) of all possible pairs of samples located on a sampling line. For every pair of samples compared, eight possible trends exist, each having a probability of random occurrence equal to $1 / 8$. According to the assumptions of this methodology, only two trends are indicative of transport: Compared to sample 1, sample 2 may be finer, better sorted and more negatively skewed (Case B) or coarser, better sorted and more positively skewed (Case C). A significant test ( $\mathrm{Z}$-score) is used to determine a preferred transport direction with a certain level of confidence. The transport direction is accepted if $\mathrm{Z}$ is larger than the corresponding value for different levels of confidence:

$$
\begin{gathered}
\mathrm{Z}=\frac{\mathrm{x}-\mathrm{Np}}{\sqrt{\mathrm{Npq}}}>1.645(0.05 \text { level of significance }) \text { or } \\
>2.33 \text { (0.01 level of significance) }(2)
\end{gathered}
$$

where $\mathrm{x}$ is the number of pairs representing a particular case in one of the two opposing directions, $\mathrm{N}$ is the total number of possible pairs.

$\left(\mathrm{N}=\frac{\mathrm{n}^{2}-\mathrm{n}}{2}\right), \mathrm{n}$ is the number of samples in a sequence, and $\mathrm{p}$ is the probability of random occurrence, which is equal to 0.125 , and $q=1-p$ ). 
The final acceptance or rejection of a trend is made by the qualitative evaluation of a multiple correlation coefficient $\left(\mathrm{R}^{2}\right)$ between the mean, sorting and skewness of each sample contained in the sequence (McLaren et al., 1993).

The procedure proposed by Gao and Collins (1992) defines trend vectors for a grid of sampling sites using grain size trends that differ slightly from those proposed by McLaren and Bowles (1985). According to these authors, four grain size trends are associated with net transport directions:

Type 1: F, B, - (finer, better sorted and more negatively skewed)

Type 2: $\mathrm{C}, \mathrm{B},+$ (coarser, better sorted and more positively skewed)

Type 3: C, B, - (coarser, better sorted and more negatively skewed)

Type 4: F, B, + (finer, better sorted and more positively skewed)

Trend vectors are defined comparing the grain size parameters of each sample with its neighbor. Neighboring sampling sites are identified on the basis of a characteristic distance that represents the space scale of sampling. The analysis considers only those sampling sites lying within the characteristic distance. Dimensionless trend vectors are drawn for those sites that present any of the four trend types, the direction of the vector running from the site with higher sorting coefficient. Vector summation produces a single vector at each sampling site, which are then filtered applying an averaging operation in order to remove any high frequency noise. The application of the filtering procedure produces "transport vectors" that represent net transport paths. The full details of this methodology are found in Gao and Collins (1992).

The method of Le Roux (1994b) is based upon the premise that if a transport trend is defined by an increase or decrease in the values of specific grainsize parameters or a combination of parameters, it must lie along the maximum gradient of these values. Transport in shallow marine environments is inferred to take place along wide, unidirectional fronts rather than from point-to-point as assumed in the previous methods, with the maximum gradient lying normal to the fronts. Groups of five stations are therefore used to determine the vector mean azimuth and vector strength of the transport paths.

The grain-size parameters $\left(\mu, \sigma^{2}, \mathrm{Sk}\right)$ for each station are first combined into a single, dimensionless number, with each parameter considered to be of equal importance. However, the concept also allows for differential weighting of the parameters if needed. The basic method requires that there should be a central station and four satellite stations located on the principal radials $\left(360^{\circ}, 090^{\circ}\right.$, $180^{\circ}$ and $270^{\circ}$ ), at equal distance from the center, so that the dimensionless grain-size parameters can be substituted for the proportional frequencies of recorded directions in conventional vector analysis. To allow for an irregular distribution of station localities, however, an iterative trigonometric technique is used to determine the values at these localities. The four trend types described above can be analyzed, with the option to either use individual trend types or to employ the trend type with the maximum vector strength for each group of stations. The distribution of the resultant vectorial data is analyzed using the Watson non-parametric test, to determine whether it is preferential or uniform. This test for modulo $360^{\circ}$ azimuth data is stronger than the Kuiper test and uses the following statistic (Watson, 1966). The vectorial data, $\theta_{\mathrm{i}}\left(\right.$ modulo $\left.360^{\circ}\right)$ are first sorted from the smallest to the largest value and given indices from $\mathrm{i}=1$ to $\mathrm{i}=\mathrm{n}$. The test statistic $\mathrm{u}^{2}$ is given by:

$$
\begin{gathered}
\mathrm{u}^{2}=\left(\mathrm{u} *^{2}+0.1 / \mathrm{n}^{2}-0.1 / \mathrm{n}\right)(1+0.8 / \mathrm{n}) \\
\text { where } \mathrm{u} *^{2}=\Sigma\left(\theta_{\mathrm{i}} / 360\right)^{2}-2 / \mathrm{n} \Sigma\left(\mathrm{i} \theta_{\mathrm{i}} / 360\right)+ \\
1 / \mathrm{n} \Sigma\left(\theta_{\mathrm{i}} / 360\right)+\mathrm{n}\left\{1 / \mathrm{n} \Sigma\left(\theta_{\mathrm{i}} / 360\right)-\right. \\
\left.\left[1 / \mathrm{n} \Sigma\left(\theta_{\mathrm{i}} / 360\right)\right]^{2}+1 / 12\right\}
\end{gathered}
$$

The critical value of the test statistic, $\alpha_{\alpha}{ }^{2}$, is 0.187 for $\alpha=5 \%$ and 0.267 for $\alpha=1 \%$. If $\mathrm{u} *^{2}$ is less than $\mathrm{u}_{\alpha}{ }^{2}$, the null hypothesis can be rejected with a confidence of (100- $\alpha) \%$ and the alternative hypothesis (i.e. that the distribution is non-random) can be accepted.

\section{RESULTS}

\section{Sedimentological characterization of the study area}

The spatial distribution of textural classes during both seasons, reveals that most of Lirquén Harbor is dominated by sandy sediments. The mean size distribution pattern shows that coarse-grained 
sediments $(0.4$ to $4.0 \phi)$ are associated with the eastern sector whereas fine-grained sediments with a mean grain-size of $4.1 \phi$ to $6.2 \phi$ are restricted to the west (Fig. 2).

In general, during winter the bottom sediments tend to become coarser, better sorted and more positively skewed towards the east. Coarsening of sediments along with better sorting and increasing negative skewness is observed in the same sector during summer (Fig. 2).
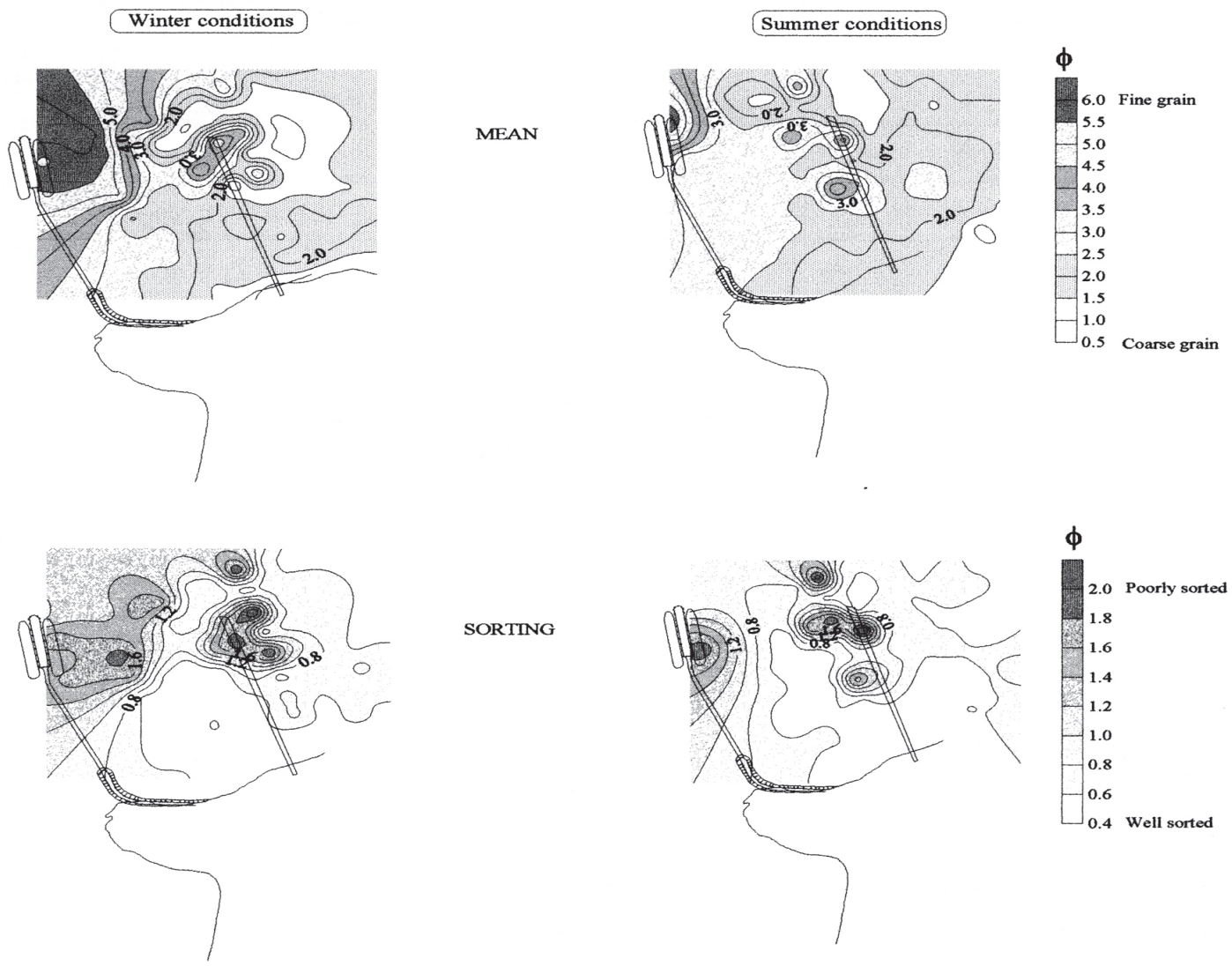

SORTING
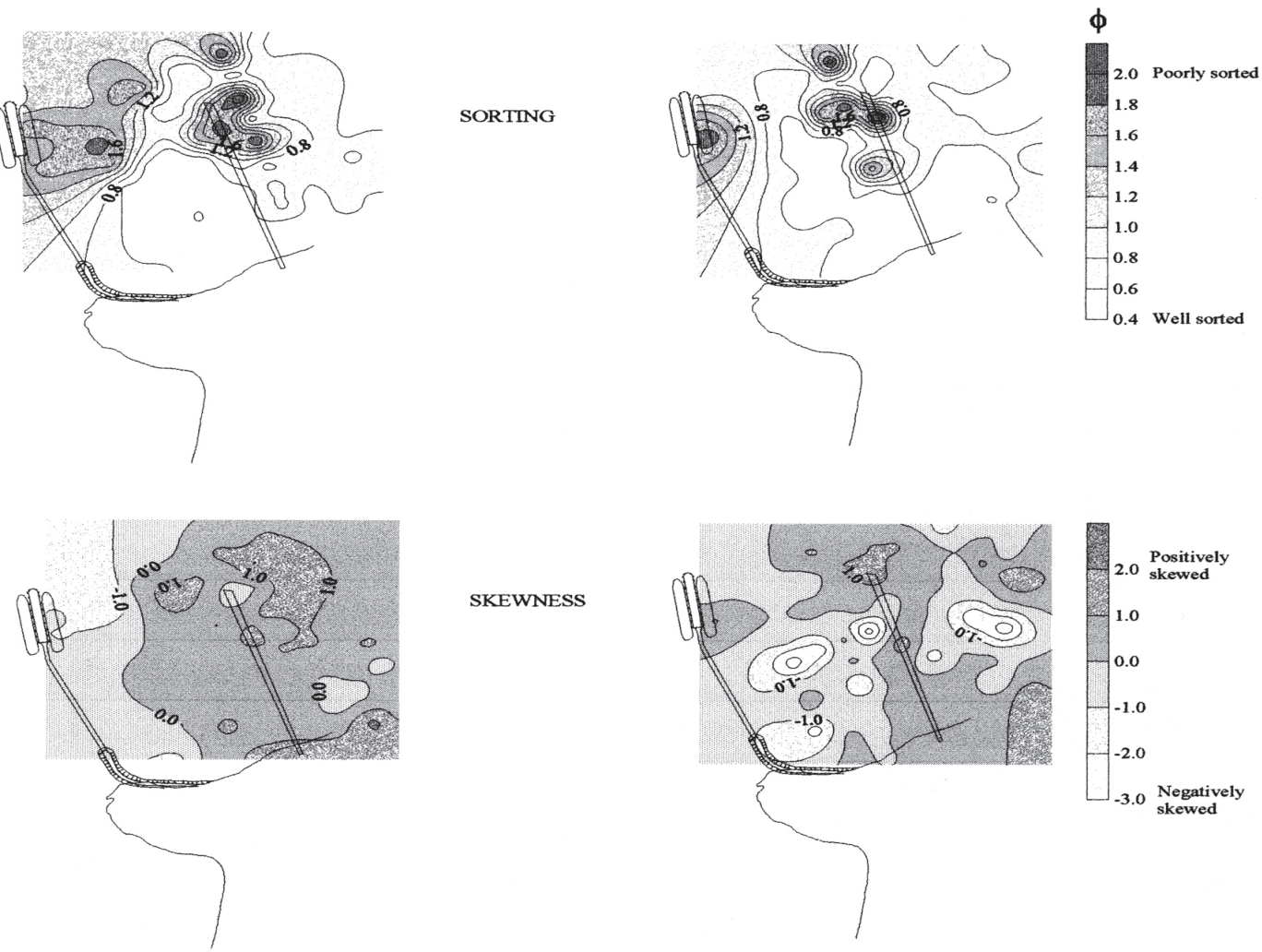

Figure 2.

Figure 2. Spatial distribution of mean grain size (in $\phi$ units), sorting coefficient (in $\phi$ units) and skewness of surficial sediments during extreme weather conditions.

Figura 2. Distribución espacial del parámetro de tamaño medio (en unidades phi), selección (en unidades phi) y de asimetría durante condiciones de invierno y verano. 


\section{Wind and current characterization during extreme weather conditions}

The statistical characteristics of the winds and mean currents measured during the sampling periods are summarized in Tables 1 and 2.

Northwesterly winds dominated throughout the winter survey with a mean velocity of $9.1 \mathrm{~m} / \mathrm{s}$ (Fig. $3 a)$. An intense wind event occurred on June $19^{\text {th }}$ during which winds were predominantly from the north and blew with speeds in excess of $15 \mathrm{~m} / \mathrm{s}$ for 12 consecutive hours. During fair-weather periods (June 18-19 and 24-26), wind speeds were low $(<6$ $\mathrm{m} / \mathrm{s}$ ) and the winds predominantly blew from the southeast or southwest. During these periods, nearbottom current velocities were usually weak $(<10$ $\mathrm{cm} / \mathrm{s}$ ). During the high wind events recorded on June 19-23, maximum near-bottom current velocities reached $20 \mathrm{~cm} / \mathrm{s}$ at both moorings (Fig. 4a). Light winds from the southwest prevailed during the summer survey with an average speed of $5.3 \mathrm{~m} / \mathrm{s}$ (Fig. 3b). Events with wind speeds in excess of 10 $\mathrm{m} / \mathrm{s}$ occurred on December 13-16. Weak bottom currents $(<10 \mathrm{~cm} / \mathrm{s})$ were recorded during the summer survey (Fig.4b).

The progressive vector diagrams (PVD) show the residual circulation at the near-bottom levels of measured currents. Until June 22, the water circulation pattern was towards the harbor (SW) at the $15 \mathrm{~m}$ level (Fig. 5a). By the end of June 22 the pattern changed to the northeast (out of the harbor). However, the water circulation at the near-bottom level of mooring $\mathrm{B}$ registered no changes during this period, remaining towards the SW (Fig.5a). The current at all three levels was not constant, especially at mooring $\mathrm{A}$, due to the greater variability of the
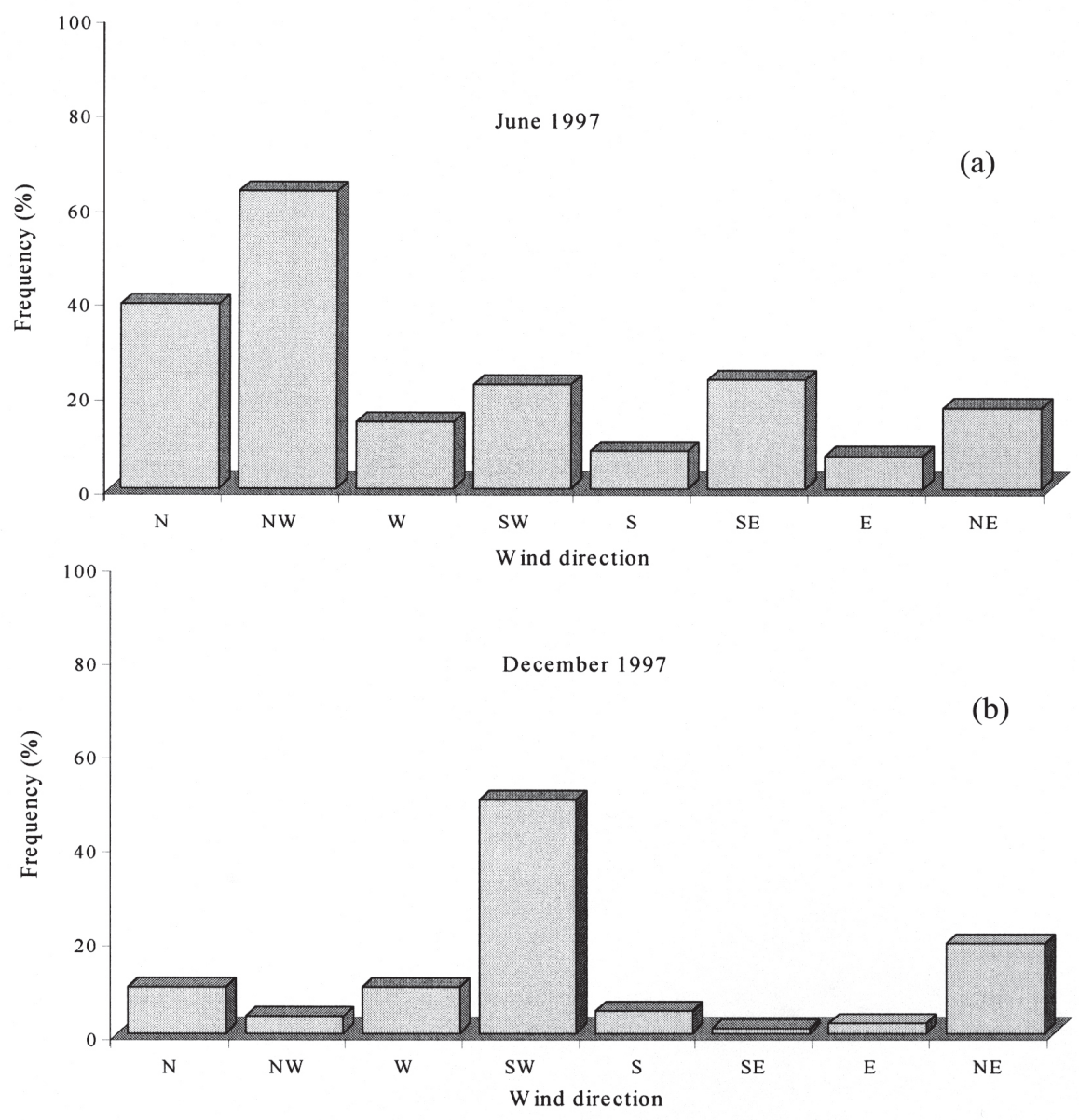

Figure 3. Frequency histograms of wind direction for: a) the winter survey and b) the summer survey.

Figura 3. Histograma de dirección del viento durante condiciones de a) invierno y b) verano. 
winds measured in June (Table 1). The residual current direction at all levels was to the southwest mainly as a result of the intense forcing of the northnorthwesterly winds. During summer, the southwesterly trend persisted at the $7 \mathrm{~m}$ level of mooring B. Until December 15, the water circulation at the bottom level of mooring A (16 m depth) was towards the southeast, changing to northwesterly at the end of December 16. The current at this level presents the greatest variability of all (Table 2). The residual current direction for the bottom level of mooring $\mathrm{B}$ remained to the southwest, nevertheless the current at $16 \mathrm{~m}$ (mooring $\mathrm{A}$ ) presents a pattern in which the flow was mainly directed toward the southeast (Fig.5b).

A linear correlation analysis between the mean and tidal current (obtained through a short high-pass filter) revealed that the flow regime observed in
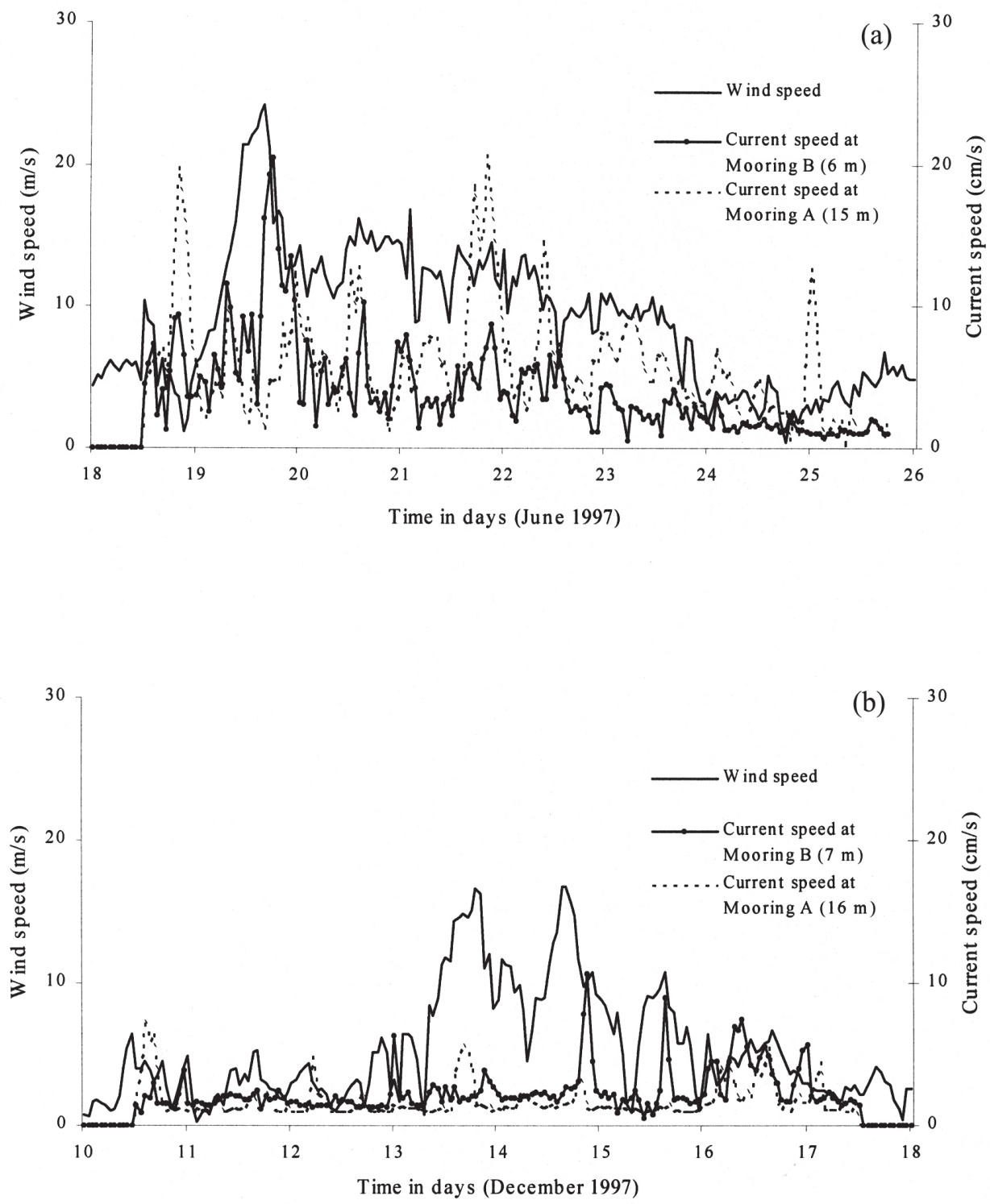

Figure 4. Time series plots of wind velocity and near-bottom mean current velocities recorded during a) the winter and b) summer survey.

Figura 4. Velocidades del viento y de la corriente registradas durante a) junio y b) diciembre 1997. 

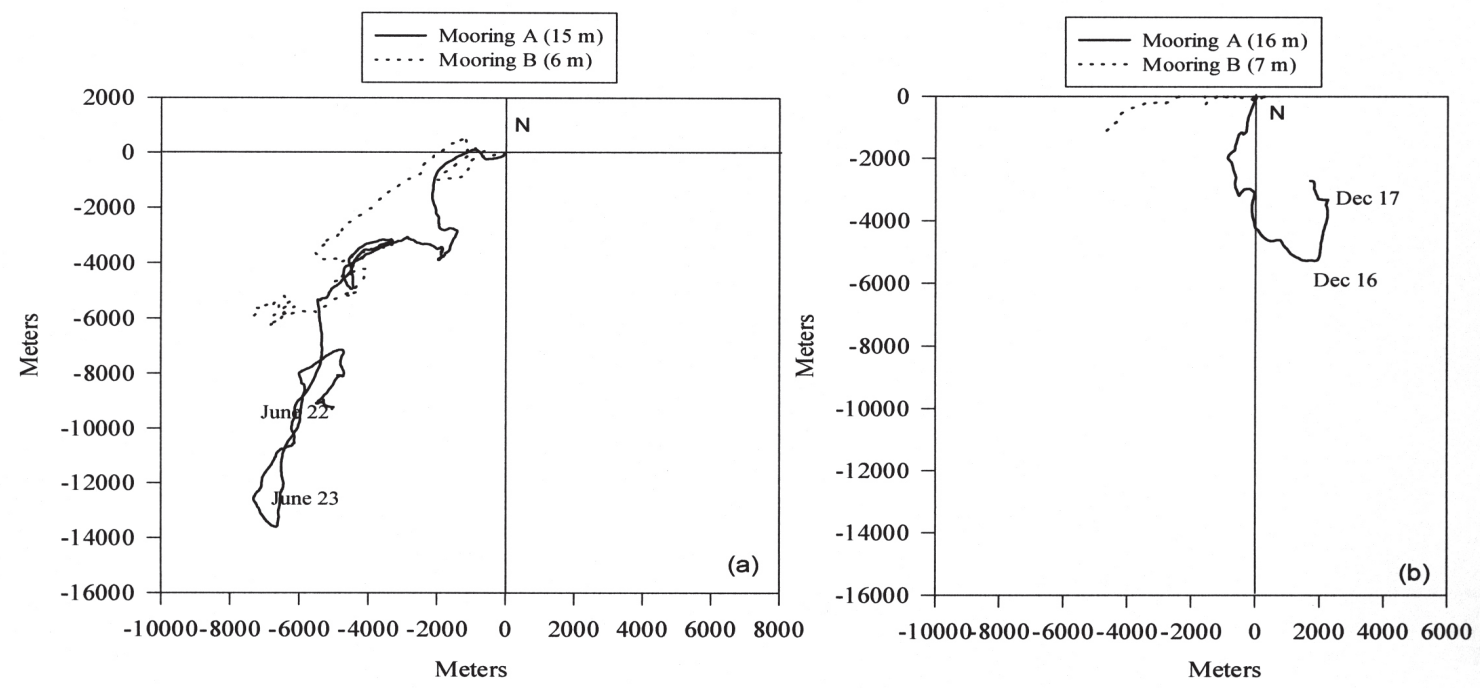

Figure 5. Progressive vector diagrams at the levels of measured currents during the a) winter and b) summer survey.

Figura 5. Diagramas de vector progresivo de la corriente bajo condiciones de a) invierno y b) verano.

Lirquen Harbor during the survey period is primarily tidally forced. The high-pass current velocity data indicate that the peak flood currents are stronger than the peak ebb currents at all levels (flood-ebb asymmetry; Tables 1 and 2). During the strong wind periods, wind forcing was especially evident as the strongest near-bottom currents were recorded during these events.

\section{Wave predictions}

Tables 3,4,5 and 6 present the results of the NARFET wave predictions based on the wind data measured in June and December 1997, the near-bottom maximum orbital velocities $\left(\mathrm{u}_{\mathrm{m}}\right)$ calculated from the wave period and the orbital diameter, the threshold orbital velocity $\left(\mathrm{u}_{\mathrm{t}}\right)$ calculated from Komar and Miller (1975), the critical shear velocity for bedload transport $\left(\mathrm{u}_{*_{\mathrm{cr}}}\right)$ and the ripple-enhanced combined shear velocity $\left(\mathrm{u}_{*_{\mathrm{c} w e}}\right)$ calculated according to Li and Amos (2001). Since the NARFET model provides estimates of the deepwater wave height, the variation in the heights of the shoaling waves (at 10 and $5 \mathrm{~m}$ water depth) were calculated using Airy-wave theory. The results of the hindcasting model indicate that wave sizes in Concepción Bay are limited by the restricted fetch due to the landforms surrounding the body of water and the Quriquina. The maximum fetch estimated was $11.8 \mathrm{~km}$ for the predominant northwesterly winds. The largest deepwater waves (1.7 $\mathrm{m}$ at $20 \mathrm{~m}$ depth) predicted for June 1997 are generated when the northerly winds blow with speeds in excess of $15 \mathrm{~m} / \mathrm{s}$ for 12 consecutive hours (Table 3). These winds generated the highest nearbottom maximum orbital velocity $\left(u_{m}\right)(77.6 \mathrm{~cm} / \mathrm{s}$ in $5 \mathrm{~m}$ water depth). The smallest waves $(0.4 \mathrm{~m})$ predicted for June occur when the wind blows from the southwest (from land to sea) (Table 5). Peak wave periods ranged from 2.4 to 4.7 s. For December 1997, the model predicted smaller waves as the wind blew predominantly from the land (SW), although as a result of the intensification of the southwesterly winds on December $13^{\text {th }}$, the predicted wave height reached $1.1 \mathrm{~m}$. Wave period during this period was $3.6 \mathrm{~s}$ (Table 6).

\section{Sediment transport by waves and by combined flows}

For the pure-wave case, sediment is transported if the near-bottom maximum orbital velocity $\left(\mathrm{u}_{\mathrm{m}}\right)$ exceeds the corresponding threshold velocity $\left(u_{t}\right)$ as computed with Eq. 1. Below this threshold criterion no transport is assumed. According to these calculations, in June the threshold orbital velocity was exceeded only in water depths of 10 and 5 
Table 1. Descriptive statistics for winter wind, mean and tidal current.

Tabla 1. Estadística de las series de viento, corriente total y mareal (invierno).

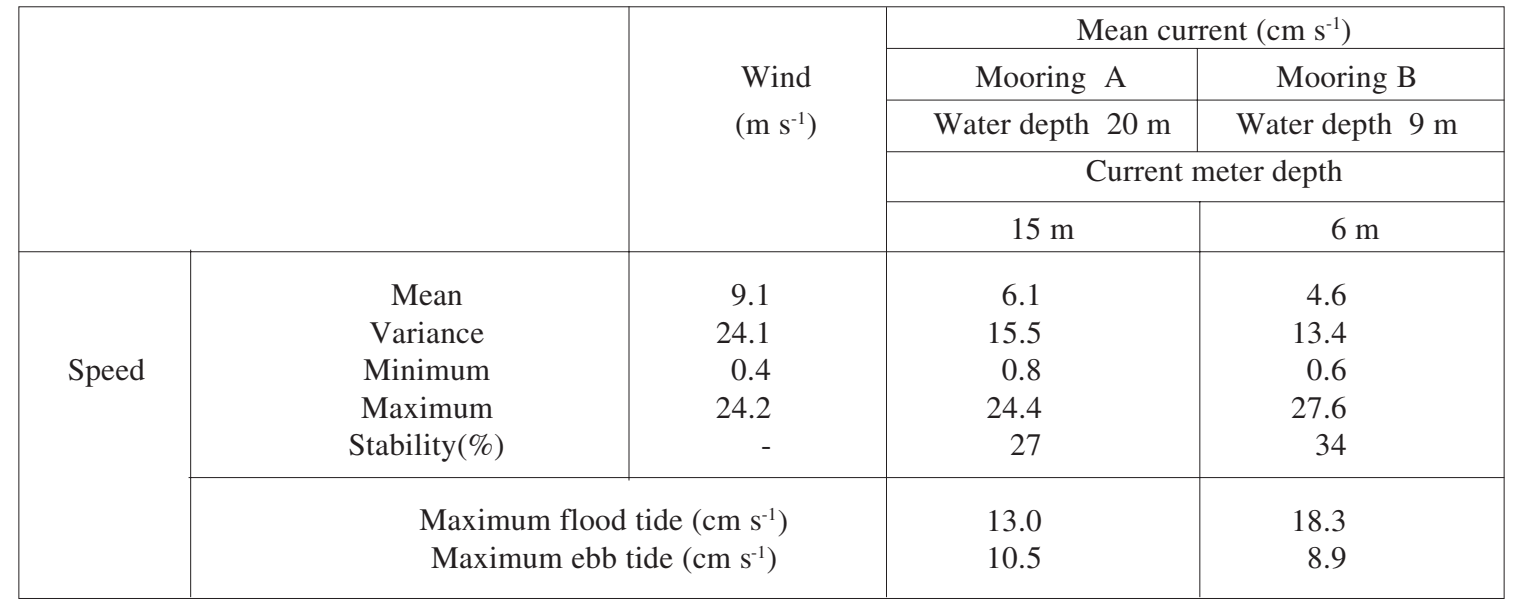

Table 2. Descriptive statistics for summer wind, mean current and tidal current.

Tabla 2. Estadística de las series de viento, corriente total y mareal (verano).

\begin{tabular}{|c|c|c|c|c|}
\hline & & \multirow{5}{*}{$\begin{array}{l}\text { Wind } \\
\left(\mathrm{m} \mathrm{s}^{-1}\right)\end{array}$} & \multicolumn{2}{|c|}{ Mean current $\left(\mathrm{cm} \mathrm{s}^{-1}\right)$} \\
\hline & & & Mooring A & Mooring B \\
\hline & & & Water depth $20 \mathrm{~m}$ & Water depth $9 \mathrm{~m}$ \\
\hline & & & \multicolumn{2}{|c|}{ Current meter depth } \\
\hline & & & $16 \mathrm{~m}$ & $7 \mathrm{~m}$ \\
\hline \multirow{7}{*}{ Speed } & Mean & 5.3 & 1.8 & 2.6 \\
\hline & Variance & 15.7 & 1.6 & 3.7 \\
\hline & Minimum & 0.3 & 0.8 & 0.6 \\
\hline & Maximum & 16.9 & 8.6 & 23.8 \\
\hline & Stability $(\%)$ & - & 29 & 32 \\
\hline & \multirow{2}{*}{\multicolumn{2}{|c|}{$\begin{array}{l}\text { Maximum flood tide }\left(\mathrm{cm} \mathrm{s}^{-1}\right) \\
\text { Maximum ebb tide }\left(\mathrm{cm} \mathrm{s}^{-1}\right)\end{array}$}} & 4.6 & 9.9 \\
\hline & & & 3.2 & 4.8 \\
\hline
\end{tabular}

meters, during the storm-event recorded on June $19^{\text {th }}$ when wind speeds exceeded $15 \mathrm{~m} / \mathrm{s}$ for 12 consecutive hours (Table 3 ). The wave-orbital velocities generated by the predominant northwesterly winds resuspended only those sandy sediments present in $5 \mathrm{~m}$ water depth (Table 4). Waves generated by the weak offshore (southwesterly) winds were not capable of mobilizing the shallow water sediments (in water depths of 10 and $5 \mathrm{~m}$ ) (Table 5).

No sediment transport occurred in deeper water (20 meters) under the action of waves alone. According to Héquette and Hill (1993), sediment resuspended by waves is entrained by the mean flow, thus the near-bottom current data of Mooring B indicates that the mean flow on June $19^{\text {th }}$ was mainly directed toward the west, suggesting that the resuspended sediments were mainly transported outside of the harbor (erosion of material) (Table 3 ). In the case of the sandy sediments resuspended by the waves associated with the northwesterly winds, the near-bottom flow also dispersed these in a westerly direction (Table 4), as the current in $6 \mathrm{~m}$ water depth had a residual direction toward the west. In December, the calculations indicate that the threshold orbital velocity was exceeded only in $5 \mathrm{~m}$ water depth during the intensification of the southwesterly winds recorded on December $13^{\text {th }}$. Consequently, some material was lost for the harbor as the near-bottom current in 7 meter water depth 
flowed toward the west during that day (Table 6).

As pointed out by Grant and Madsen (1979), unidirectional currents and wave orbital motions interact in a non-linear fashion that causes a total boundary layer of greater magnitude than the stress produced by wave motion alone, and consequently combined flows may initiate sediment motion at lower velocities than those predicted for waves alone.

According to the SEDTRANS96 model, the initiation of bedload transport under combine waves and currents will occur when the rippleenhanced combined shear velocity $\left(\mathrm{u}_{*_{\mathrm{cwe}}}\right)$ exceeds the bedload critical shear velocity $\left(\mathrm{u}_{*_{\mathrm{cr}}}\right)$. The results show that during the northerly storm of June $19^{\text {th }}$ sediment transport of fine sediments occurred $\left(u_{*_{\mathrm{cwe}}}>\mathrm{u}_{*_{\mathrm{cr}}}\right)$ in $20 \mathrm{~m}$ water depth in response to combined wave oscillatory currents and mean flows. The model suggested that most of the sediment load was directed towards the northwest (Table 3). Eastward transport due the interaction of waves and currents also occurred on June $20^{\text {th }}$ at $10 \mathrm{~m}$ depth (Table 4). During the period of June 24-26 no transport occurred as light offshore winds and weak near-bottom currents prevailed during this period (Table 5). On December 13, the threshold of sediment motion was exceeded in $10 \mathrm{~m}$ water depth in response to combined flows. Sediment was transported in a southwesterly direction (Table 6).

\section{Sediment transport pathways determination through grain size trend analysis}

McLaren-Bowles Methodology. For the winter samples, 28 lines were identified as having their $\mathrm{z}$-scores exceeding the $95 \%$ significance level on the basis of $\mathrm{p}=1 / 8$ (Eq. (1)). The use of a low probability criterion resulted in most lines exceeding the acceptable significance level for both directions. This situation was overcome when a higher probability criterion $(\mathrm{p}=1 / 4)$ was applied. As a result only those lines with $\mathrm{z}$-scores exceeding the $95 \%$ level of significance at $\mathrm{p}=1 / 4$ were used to infer the sediment transport direction. In order to enable the final acceptance or rejection of the trends, a multiple correlation coefficient was calculated between the three grain-size parameters of each sample present along a sequence.

The summer samples produced 13 sample lines with good statistics, applying a background probability criterion equal to $1 / 5$. Acceptable trends were confirmed on the basis of significant $\mathrm{R}^{2}$ values.

The inferred sediment transport pathways for winter conditions are shown in Fig. 6A. Three main sediment transport directions are observed. The analysis of north-south sample lines indicates strong trends of transport in a southerly direction. On average, the $\mathrm{R}^{2}$ values for these lines are high (mean $\mathrm{R}^{2}$ of 0.87 ). Analysis of the lines oriented in a west-east direction produced strong Case $\mathrm{C}$ trends showing net eastward transport, although the $\mathrm{R}^{2}$ values for the lines closer to the shoreline are relatively low, decreasing to 0.66. On the other hand, the northwest-southeastern lines indicate a significant southeastward type $\mathrm{C}$ transport with very high $\mathrm{R}^{2}$ values (mean $\mathrm{R}^{2}$ of 0.88 ). Lastly, a northeastward component was identified by the trend analysis of a southwest-northeastern line.

The grain-size parameter statistics for summer samples disclosed the presence of the southward and eastward transport already detected during the previous season (Fig. 6a), although their $\mathrm{R}^{2}$ values are smaller (mean

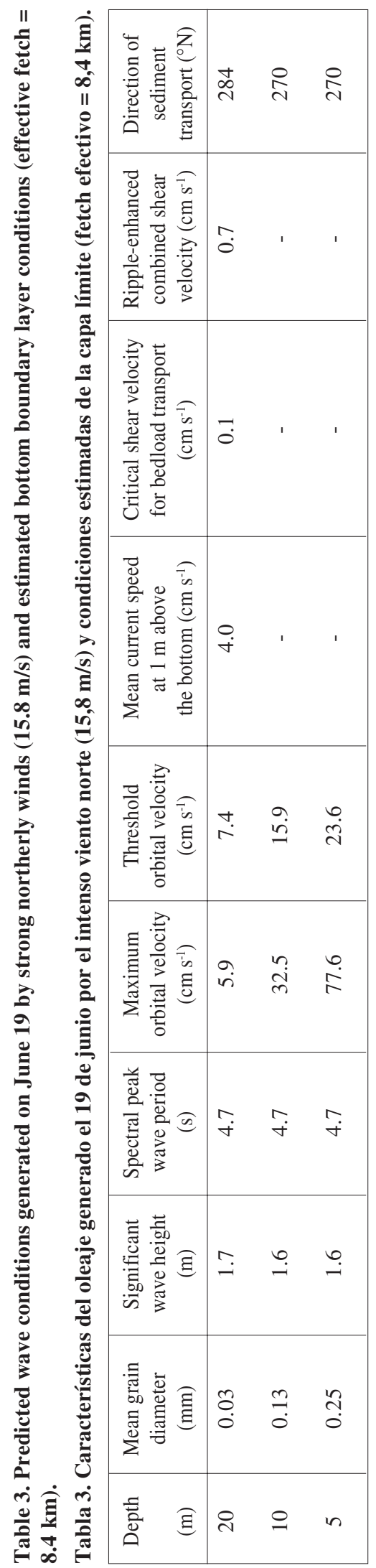



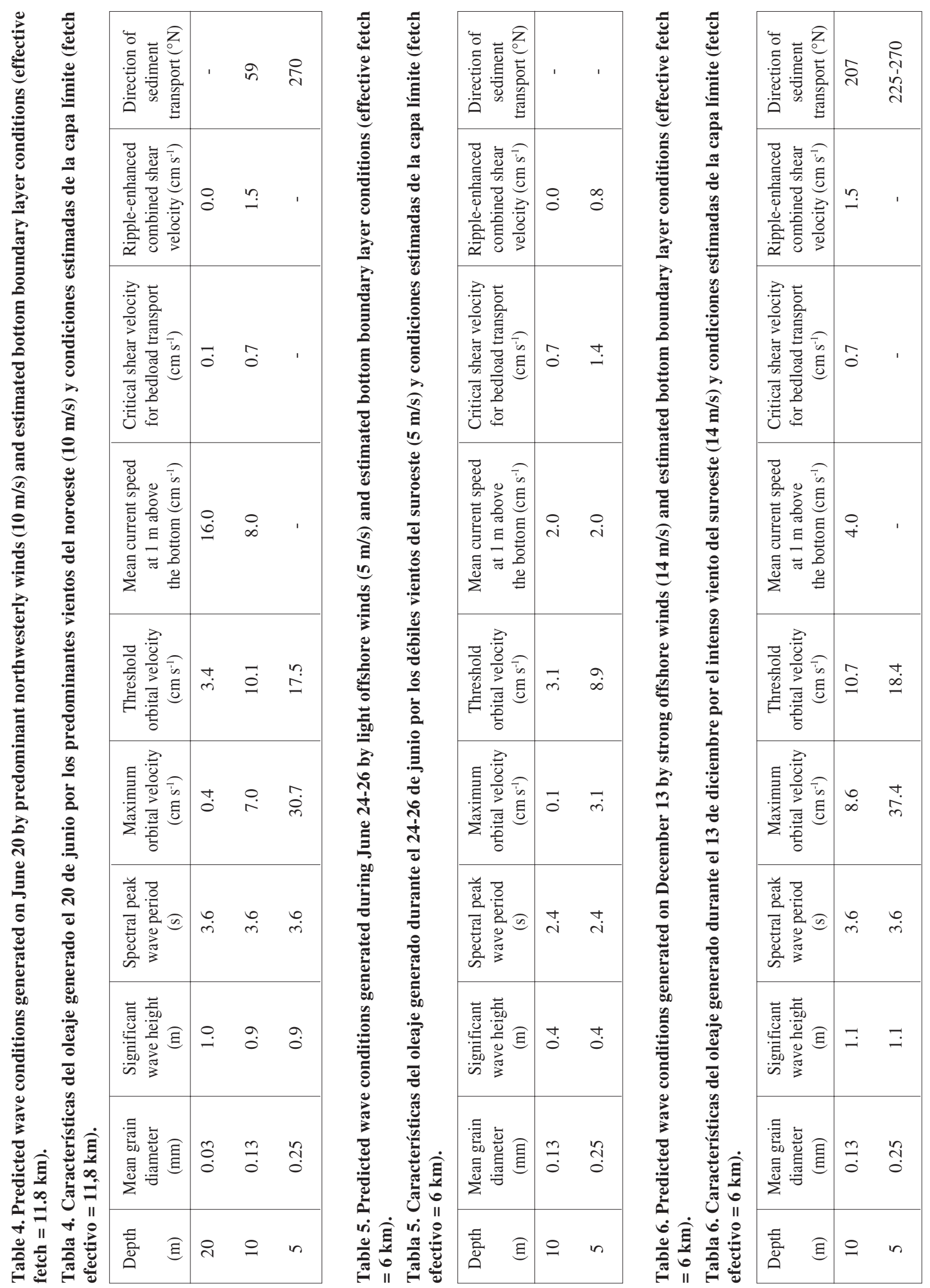

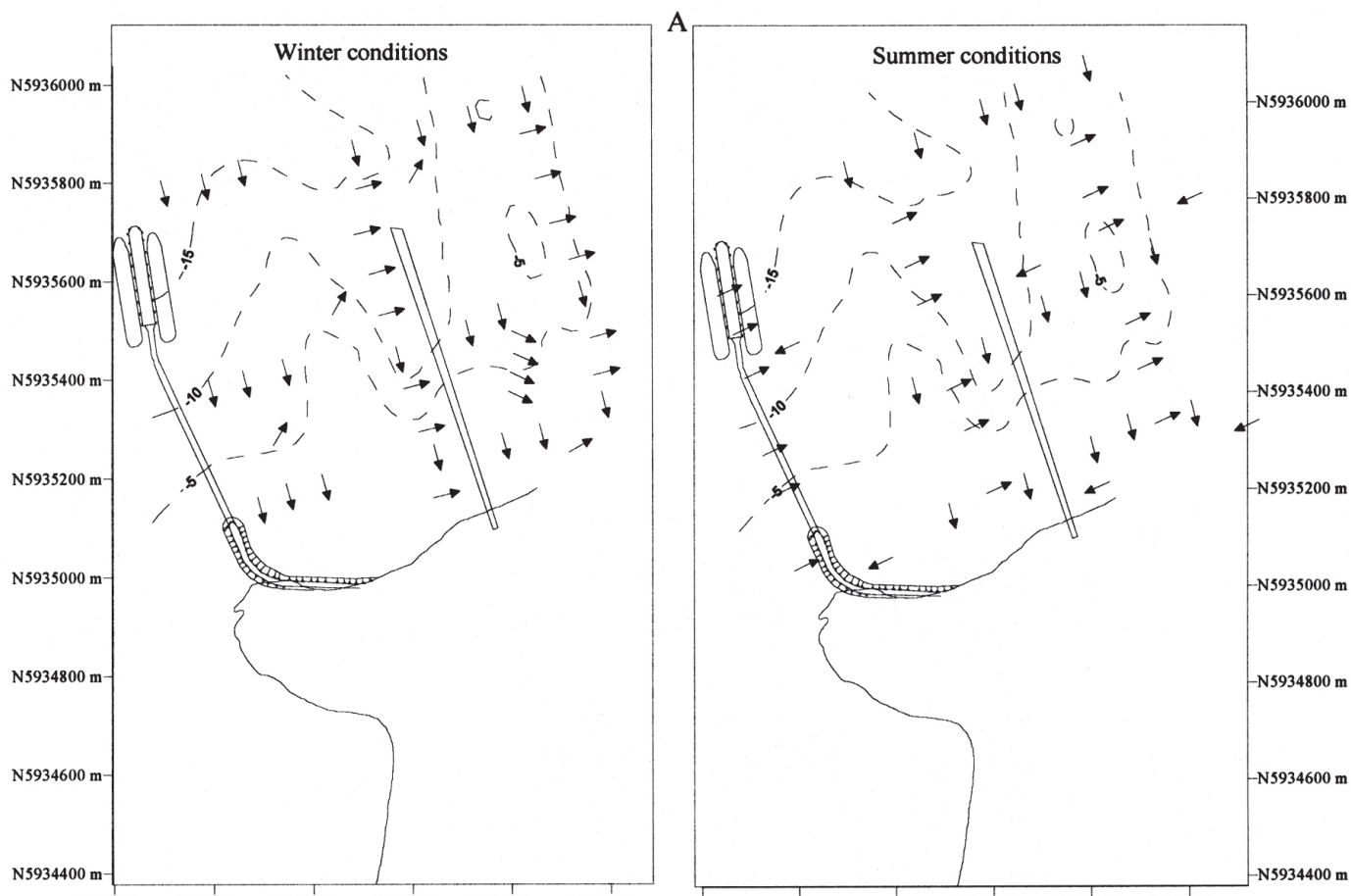

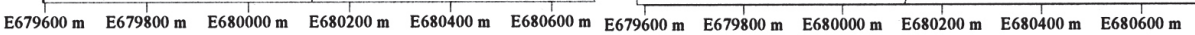
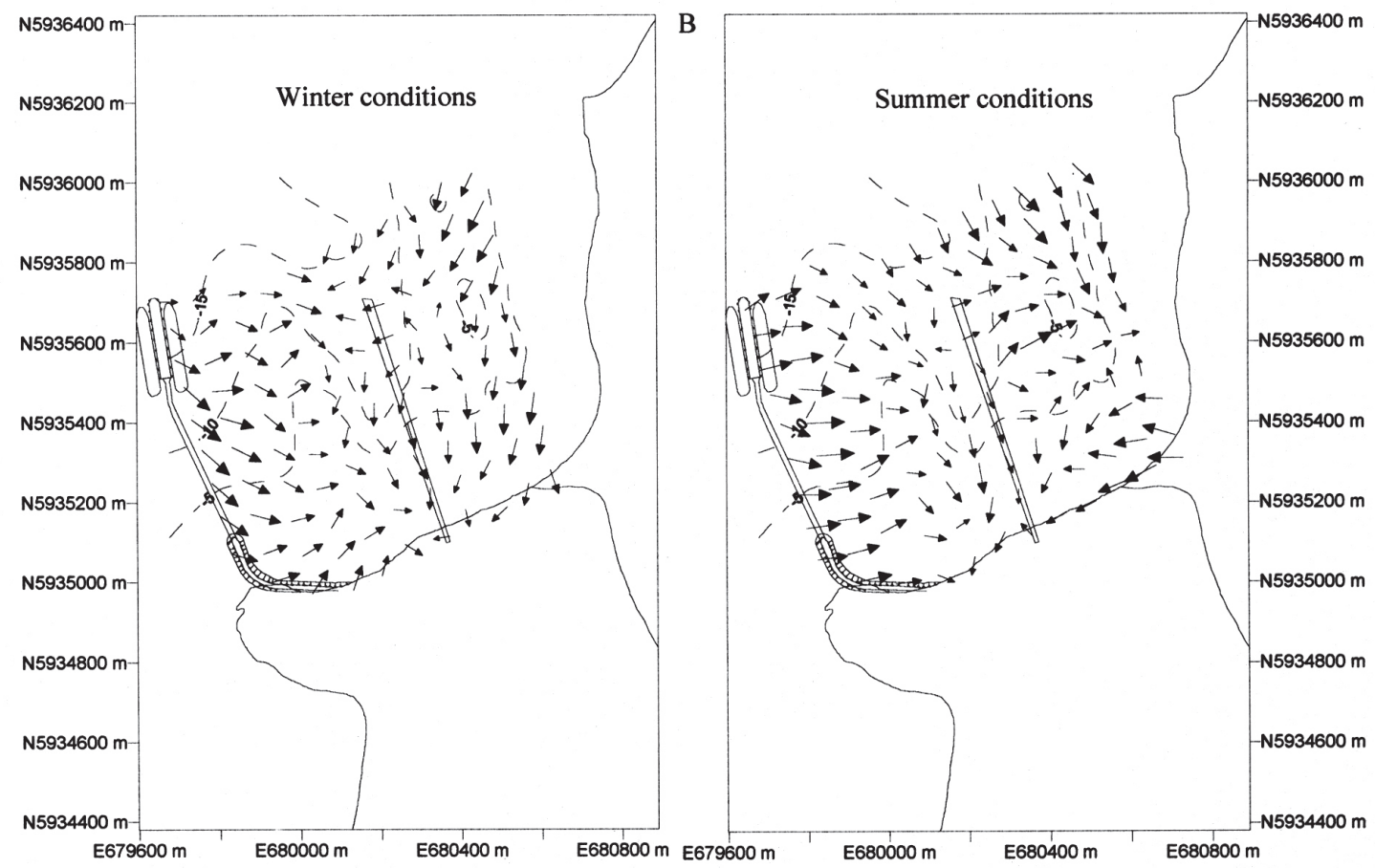

Figure 6. Sediment transport pathways in Lirquen Harbor obtained through the methodologies of a) McLarenBowles and b) Gao-Collins.

Figura 6. Patrones de transporte de sedimentos obtenidos mediante las metodologías de a) McLaren-Bowles y b) Gao-Collins. 
$\mathrm{R}^{2}$ of 0.62 and 0.63 , respectively). The southeastern transport direction recognized by the winter trend analysis was not identified in summer; instead a new Case B transport trend to the west with high $\mathrm{R}^{2}$ values $(0.81)$ was recognized.

Gao-Collins Methodology. The winter and summer sediment transport pathways in a two-dimensional sample grid are shown in Fig. 6B. The application of this procedure for the winter data revealed an alignment of transport vectors with depth contours. Near jetty 2 transport was dominantly to the southeast and east; whereas on the shoreline the transport was northeastward. To the east of jetty 1 , including the shoreline, transport to the south and southwest seems to have prevailed. In the southern sector of the jetty, the presence of converging vectors from the northwest and northeast suggests that sediment deposition was taking place.

The sediment circulation under summer conditions indicates that sediment transport near jetty 2 was mainly towards the east. This eastward transport gradually pivots to the south as jetty 1 is approached, following the bottom contours. In the sector east of the jetty, a south-southeastern transport direction prevailed in the north, turning towards the east in the center. In the southern part of this sector the transport direction changed abruptly to the west.

Le Roux Methodology. In this case all four trend types as well as a combination of all four types were employed in the analysis. The Watson nonparametric test rejects the null hypothesis of random variability at the $99 \%$ confidence level for all four trends in the winter pattern and Types 2 and 3, as well as the combination of all four types in the summer pattern.

For the winter data, the different trend types yield the following vector means and magnitudes, with no filter employed: Type $1: 220^{\circ}, 33 \%$; Type $2: 096^{\circ}$, $40.3 \%$; Type 3: $095^{\circ}, 32.9 \%$; Type $4: 152^{\circ}, 48.4 \%$. Three of the four trend types indicate a vector mean in the southeastern quadrant, with type 4 having the highest vector magnitude. Both type 2 and 3 trends show east-southeasterly transport in the westernmost part of the harbor, swinging towards the southsoutheast along jetty 1 . East of the latter, trends are more variable but dominantly towards the north in the central portion and towards the south in the southeastern and northeastern corners of the study area (Fig. 7a). Type 4 produces a very well developed pattern towards the south-southeast in the western part of the study area, with very variable and weakly developed vectors in the east.

The summer data produce the following vector means and magnitudes with no filter employed: Type 2: $096^{\circ}, 30.6 \%$; Type 3: $103^{\circ}, 37.8 \%$; All trends: $096^{\circ}, 20 \%$. Again, the statistically valid trends fall within the southeastern quadrant, all three trends corresponding closely to types 2 and 3 of the winter data. Figure $7 \mathrm{~b}$ shows the transport vectors produced by a combination of all trend types. Along the western edge of the study area, transport is towards the east-northeast. This trend continues in the central-eastern part of the harbor, swinging towards the south-southeast in the vicinity of jetty 1 . In the southeastern corner of the study area, transport is towards the northwest. The northeastern part of the study area is characterized by trends running south and southeast, whereas the northern margin shows a west-southwesterly pattern. Areas with conflicting directions occur to the west and northeast of jetty 1 .

\section{DISCUSSION}

\section{Potential sediment transport}

According to Soulsby (1997), the predominant mode of transport over the study area will be suspended load as most sediment is composed of grains less than $0.2 \mathrm{~mm}(>2 \phi)$ in diameter. The results of our analysis suggests that resuspension of sediments present in the study area occurs only during high wind events (i.e., $\bullet 10 \mathrm{~m} / \mathrm{s}$ ), resuspension of deepwater sediments (at $20 \mathrm{~m}$ depth) is caused by the combined action of waves and currents, whereas resuspension of shallow-water sediments (in water depths of no more than $10 \mathrm{~m}$ ) is mainly caused by wave action alone as a result of the limited fetch in Concepcion Bay. As the residual water circulation of the study area has a strong west component, reworked sediments are likely to be entrained outside of the harbor. Using the frequency of the wind speeds recorded during this study as a measure of local energy levels, resuspension and transport would be more frequent during winter as winds exceeding 10 $\mathrm{m} / \mathrm{s}$ were attained with a frequency of $39 \%$ in June and $13 \%$ in December. However, winds records from 1969 to 1978, obtained from the meteorological station at the Carriel Sur Airport, show that the frequency of winds in excess of $10 \mathrm{~m} / \mathrm{s}$ is less than $6 \%$ throughout the 9-year period (CICLO, 1992).

The meteo-hydrodynamic conditions measured in this survey can not be considered as being typical 


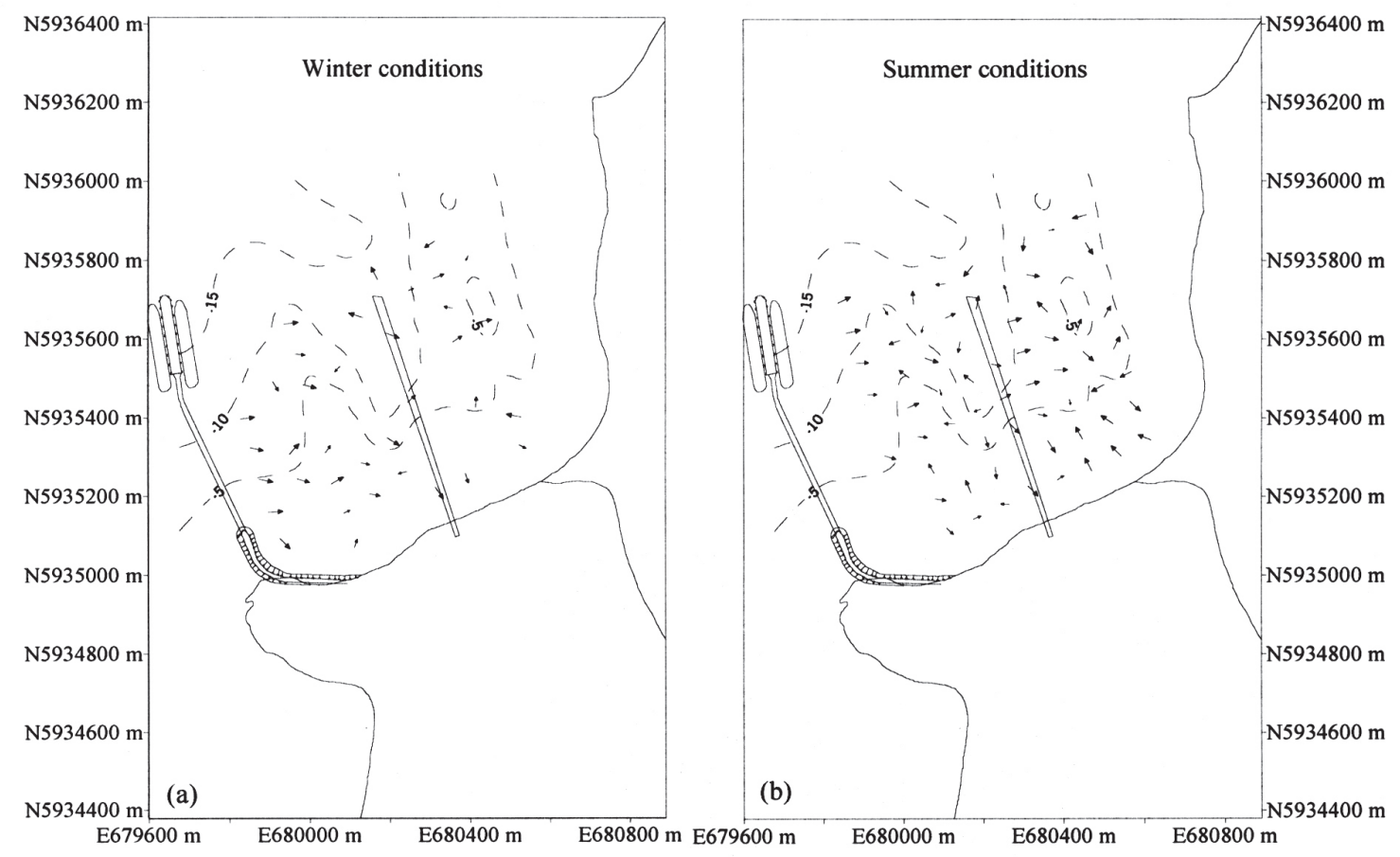

Figure 7. Sediment transport pathways in Lirquen Harbor obtained through the Le Roux methodology and produced by a) Type 2 trend and b) a combination of all trend types.

Figura 7. Patrones de transporte de sedimentos obtenidos mediante la metodología de Le Roux considerando a) la tendencia Tipo 2 y b) una combinación de todos los tipos de tendencias.

of winter and summer, as the occurrence of El Niño event in 1997 intensified this condition. Thus sediment transport in Lirquen Harbor probably takes place sporadically and under energetic forcing. The detected tidal asymmetry would result in a net flood transport of material as sediment transport is proportional to a third to fourth power of the flow velocity, which strongly amplifies the difference in magnitude of maximum ebb and flood tidal current velocities (Fry and Aubrey, 1990). This combination of factors leads to suggest that Lirquen Harbor acts as a depositional area most of the time.

\section{McLaren- Bowles methodology}

According to the results obtained by the McLarenBowles procedure, the general transport pattern of the study area is maintained through both seasons with slight modifications. However, an analysis of variance (ANOVA) of the grain size parameters revealed a significant seasonal variability $(95 \%$ confidence level) between the sorting and skewness of winter and summer sediment samples. On this basis and taking into account the sedimentation period represented by the grab samples (6-8 months), more significant changes in seasonal transport patterns should be expected since apparently the grain-size parameters present in Lirquén Harbor are sensitive to environmental and seasonal changes. Therefore, the low capacity to recognize the seasonal variations in transport patterns of the McLaren-Bowles methodology could be explained by the limitations of the line-by-line approach applied to a bi-dimensional sampling grid. The subjectivity involved in the selection of the sampling sequences probably prevents the identification of other transport components that might also be present, since for both sampling conditions sediments were collected along the same survey lines. Another explanation for the low variability detected by this procedure is the comparison of samples spaced too far apart. In this way the results obtained could be reflecting only a part of an overall spatial macroscale (as defined by Larson and Kraus, 1995) transport process controlled by different sediment sources. In comparison with the near-bed residual water 
circulation, there is poor correlation with the sediment trends, nevertheless, the southward trend detected seems to be controlled by flood tidal currents that dominate the study area.

\section{Gao-Collins methodology}

Unlike the McLaren-Bowles approach, the results obtained through the application of the Gao-Collins procedure allowed the detection of what may be seasonal changes in the sediment circulation. The northern and central parts of the eastern sector show a summer pattern different from that of winter, changing according to the prevailing wind regime of the season. The general trend of transport vectors to follow the depth contours suggests a significant influence of bottom topography on sediment circulation.

The southward transport direction detected in winter in the eastern part of the area and the general southeastward trend recognized in summer, agree with the residual near bottom water circulation recorded by mooring $A$. This suggests that the sediment transport patterns obtained through this method seem also to reflect the influence of nearbottom currents measured at the outer site (Mooring A), which were dominantly southwesterly in winter and southeasterly in summer. Thus, according to this concept, the spatial mesoscale (as defined by Larson and Kraus, 1995) near-bed sediment circulation seems to be regulated by the submarine relief, in directing its principal axis of movement, and by bottom currents. On the other hand, the westward trend detected in winter in the northern part of jetty 1 is in good agreement with the transport path suggested by the near-bottom current data and the SEDTRANS96 model. This would reflect the influence of combined waves and bottom currents on the local sediment circulation. It is therefore suggested that the Gao-Collins methodology is capable of detecting with a better resolution the mesoscale sediment circulation, as opposed to the McLaren-Bowles methodology that would rather do it on a macroscale.

Depocenters, identified by converging vectors, are discerned under both sampling conditions with a greater degree of convergence observed during summer around jetty 1 . The southern sector of the jetty shows a depocenter during both seasons, although it is somewhat displaced towards the east in summer. The greater degree of convergence in transport vectors under summer conditions could be explained by the weaker meteorological and hydrodynamic conditions, resulting in greater deposition. The fact that the depocenters are preferentially located in the vicinity of jetty 1 is interpreted to be the result of the interference generated by the piles obstructing the flow and reducing its average velocity, thus enhancing the depositional rate of entrained particles. With respect to the depocenters located to the northwest of jetty 1 , their location coincides with the sectors that historically have needed frequent dredging to maintain navigation depths (EULA, 1993).

Aerial photographs of the study area reveal a sediment plume from the Lirquén River that is carried towards the southern sector of jetty 1 , probably by the longshore current, thus supplying material to the depocenters located here. The supply of material from the Lirquén River would not destroy the general residual pattern, since the trends in the Gao-Collins methodology are defined by comparing "neighboring" samples, as opposed to the trends established by the McLaren-Bowles procedure. Thus, the sediment transport paths obtained through the Gao-Collins approach are likely to be more representative of the mesoscale sediment circulation in Lirquén Harbor.

\section{Le Roux methodology}

Like the Gao-Collins methodology, the Le Roux approach is also capable of discriminating seasonal transport patterns, with a generally eastsoutheasterly trend along the western border of the study area in winter and east-northeasterly transport in summer. The latter may be attributed to the southwesterly winds prevailing during this season, whereas the influence of northwesterly winds during winter could account for waves being directed more towards the southeast. This may be reflected especially in the Type 4 trend pattern, which indicates south-southeasterly transport during winter along the western margin of the study area. Along jetty 1, transport swings south-southeastward during both seasons. East of this jetty, transport is directed towards the north during both seasons, but there is a northwestward-directed cell in the southeastern corner during summer that does not show up in winter. This summer trend may be explained by the fact that it is located opposite the mouth of the Lirquén River, which is supported by the observation of a well-developed plume of suspended sediment on aerial photographs. A small depocenter probably 
exists in this area due to the clashing east- and northwestflowing systems.

The Le Roux methodology also allows the identification of depocenters by using vector magnitudes as an indicator of deposition, sectors with low vector magnitudes being interpreted to be undergoing siltation. Thus on both sides of jetty 1 , low vector magnitudes and clashing transport trends may indicate areas undergoing siltation.

Conceptual model of net annual sediment circulation

For the winter data, the three methodologies agree in predicting an input of material from the west-northwest, probably derived from the interior of Concepción Bay. The observed transport trends can be attributed to waves, combined waves and mean currents and the flood tidal current. Part of this inflow of sediments rotates towards the southwest, while the rest reaches the southeastern sector, thus sediment concentrates in the corners of the harbor where relatively weaker conditions prevail (Layton, 1990). Input of material from the northeast coast is also likely, from where it is transported southwards by the longshore current produced by the refraction of northwesterly waves around Lirquén Point. This longshore transport has also been recognized by Pineda et al. (1988). Thus, sediment tends to accumulate especially at the southern part of the harbor (Fig. 8).

In summer, input of sediment from the westnorthwest through jetty 2 is maintained, but in this case the transport continues to the east of jetty 1 . Along the latter, a weakening of currents and perhaps a rotation towards the south-southeast is indicated by the vector data. The southerly transport direction in the northeastern corner of the area is maintained in both the Gao and Collins and Le Roux models. In both cases, a third source of sediment input comes from the Lirquén River, which increases the supply of material delivered to the southern part of jetty 1 .

Resuspension and subsequent transport of fine non-cohesive bottom sediments would occur rarely during short time intervals. In this way, the prevailing low hydrodynamic regime allows depocenters to continue to grow throughout the year, aggravating the siltation problem. The detected tidal asymmetry would enhance the siltation of Lirquén Harbor.

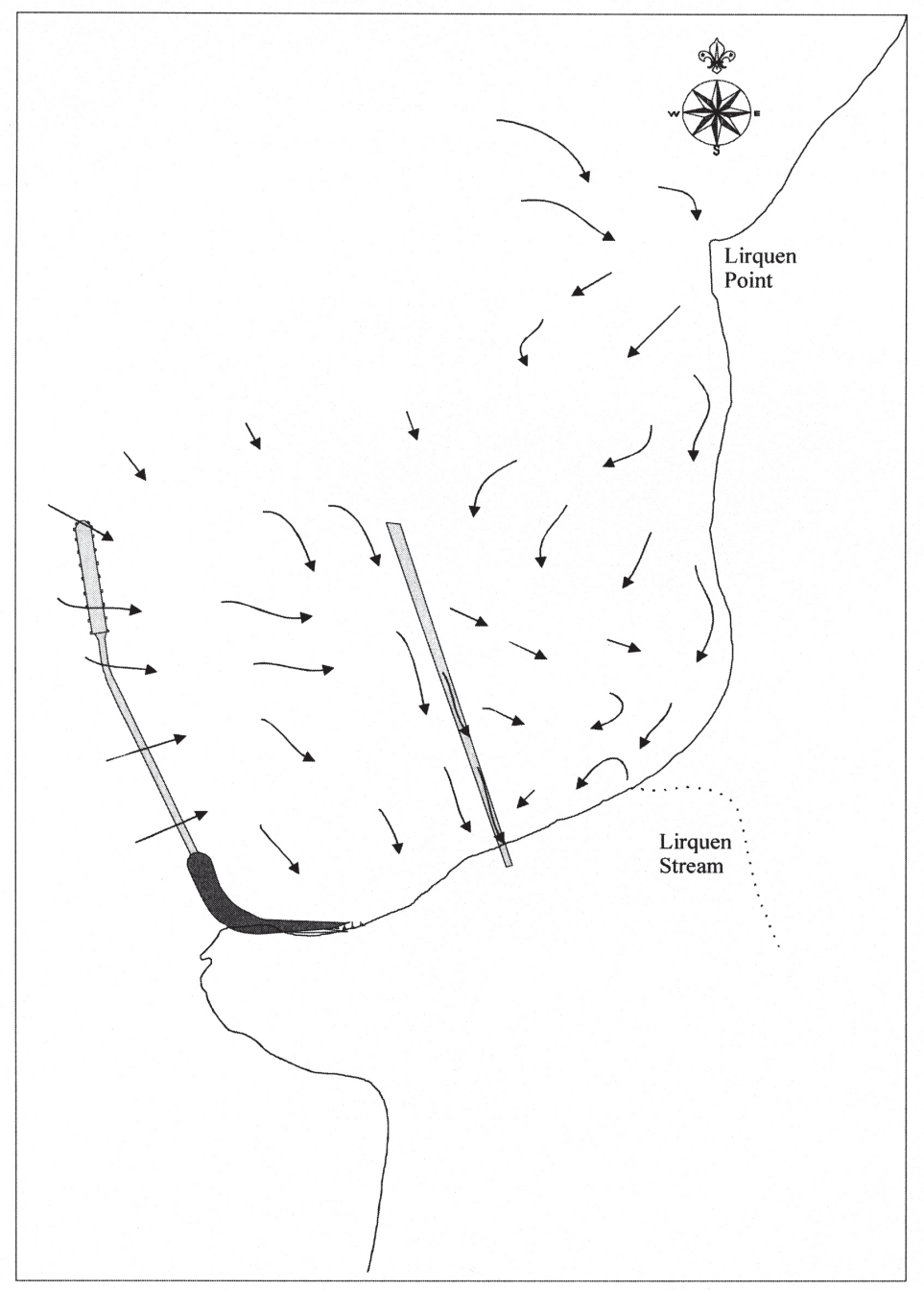

Figure 8. Conceptual model of net annual sediment circulation in Lirquen Harbor.

Figura 8. Modelo conceptual de transporte neto anual de sedimentos para Puerto Lirquén. 


\section{CONCLUSIONS}

The meteorological and oceanographic data from the present study suggest that because of the limited fetch in Concepción Bay, the direction of sediment transport in the shallow waters of Lirquen Harbor is mainly influenced by shoaling waves, whereas the combined action of waves and mean bottom currents influences transport of sediments in deep waters. Such episodic transport would take place under high meteo-hydrodynamic forcing conditions.

The current data suggests that tidal asymmetry would be another means of transporting sediment from the interior of Concepción Bay into the harbor.

The grain-size trend analysis revealed seasonal variations in sediments transport pathways and allowed us to define net annual sediment transport paths for Lirquén Harbor. The methodologies agree in predicting a sediment input from the western, northwestern and northeastern sectors. The grainsize trends reflect the influence of the prevailing meteo-hydrodynamic conditions (winds, oscillatory motions and tides) on the local sediment transport regime, and it is concluded that the status of this transport regime is characterized by net accretion. Under this condition, the fine fraction tends to be deposited preferentially around the pilings of jetty $\mathrm{N}^{\circ} 1$.

Due to its linear nature and to the lack of consideration of a characteristic distance that allows the definition of neighboring samples, the McLarenBowles methodology does not recognize the local sediment transport components. Thus, the obtained patterns seem to reflect part of the macroscale sediment transport process existing in Concepcion Bay, which is probably controlled by the flood tidal current.

The bidimensional nature of the Gao and Collins methodology and the consideration of a characteristic distance allow the recognition of local transport components, identifying a seasonal variation in transport patterns and emphasizing the effect of local bathymetry, bottom currents, and combined waves and mean bottom currents.

The Le Roux methodology also detects seasonal changes in transport patterns with a general eastsoutheasterly trend in winter and east-northeasterly transport in summer. The predicted patterns appear to be directly responding to the seasonal wind variability.
The Gao and Collins and Le Roux patterns are likely to be more representative of the mesoscale sediment circulation existing in Lirquén Harbor. Therefore, the combined application of both procedures allows a better representation of local net sediment transport patterns.

Considering the estimated annual sedimentation rate for Lirquen Harbor, it is suggested that the grainsize trends represent transport on a seasonal scale. In spite of this, for future investigations interested in determining sediment transport on a seasonal scale it is highly recommended that samples be collected using cores. This will enable the selection of those layers that according to the accurately derived accumulation rates of a specific area correspond to the latest sedimentary events, thus allowing a better definition of the time scale represented by grainsize trends.

\section{ACKNOWLEDGEMENTS}

We are grateful to Dr. Marcus Sobarzo of the EULA Center for providing the current meter data used in this study. Thanks to Patricia Virano for providing digitized maps of the study area, and to Alberto Araneda and Oscar Retamal for their assistance during the collection of sediment samples. Financial assistance for this investigation in the form of a Doctoral scholarship was provided by the German Academic Exchange Service (DAAD) and the Chilean Agency for International Cooperation (AGCI). Thanks are also due to anonymous reviewers for their helpful comments.

\section{REFERENCES}

Aguirre, L., F. Hervé and E. Godoy. 1972. Distribution of metamorphic facies in Chile. Kristallinum, 9: 7-19.

Ahumada, R. and L. Chuecas. 1979. Algunas características hidrográficas de la Bahía de Concepción $\left(36^{\circ} 40^{\prime} \mathrm{S} ; 7^{\circ} 02^{\prime} \mathrm{W}\right)$ y áreas adyacentes. Gayana Misc., 8: 3-56.

Ahumada, R., R. Morales, A. Rudolph and P. Matrai. 1984. Efectos del afloramiento costero en la diagénesis temprana de los sedimentos de la $\mathrm{Ba}-$ hía de Concepción, Chile. Bol. Soc. Biol. Concepción, 55: 135-146. 
Carriquiry, J. and A. Sánchez. 1999. Sedimentation in the Colorado River and Upper Gulf of California after nearly a century of discharge loss. Mar. Geol., 158: $125-145$.

CICLO. 1992. Informe oceanográfico y mecánica de suelos Puerto de Lirquén. Informe Preliminar. Tomo I, $137 \mathrm{pp}$.

EULA. 1993. Estudio preliminar del impacto ambiental de las labores de extracción y vertido de sedimentos en los sitios del Puerto de Lirquén y área cercana. Estudio realizado para Portuaria Lirquén S.A., 90 pp.

EULA. 1994. Informe final. Estudio de impacto ambiental. Proyecto: Ampliación del Puerto de Lirquén. Estudio realizado para Portuaria Lirquén S.A., 54 pp.

Friedman, G.M. 1979. Address of the retiring President of the International Association of Sedimentology: differences in size distributions of populations of particles among sands from various origins. Sedimentology, 26: 3-32.

Fry, V.A. and D.G. Aubrey. 1990. Tidal velocity asymmetries and bedload transport in shallow embayments. Estuar. Coast. Shelf Sci., 30: 453-473.

Gao, S. and M.B. Collins. 1991. A critique of the "McLaren Method" for defining sediment transport paths-discussion. J. Sediment. Petrol., 61: 143-146.

Gao, S. and M.B. Collins. 1992. Net sediment transport patterns inferred from grain-size trends, based upon definition of "transport vectors". Sediment. Geol., 81: 47-60.

Gao, S. and M.B. Collins. 1994. Analysis of grain size trends, for defining sediment transport pathways in marine environments. J. Coast. Res., 10: 70-78.

Gao, S., M.B. Collins, J. Lanckneus, G. De Moor and V. Van Lancker. 1994. Grain size trends associated with net sediment transport patterns: An example from the Belgian continental shelf. Mar. Geol., 121: 171-185.

Grant, W.D. and O.S. Madsen. 1979. Combined wave and current interactions with a rough bottom. J. Geophys. Res., 84: 1797-1808.

Grant, W.D. and O.S. Madsen. 1986. The continental shelf bottom boundary layer. Annu. Rev. Fluid Mech., 18: 265-305.
Héquette, A. and P.R. Hill. 1993. Storm-generated currents and offshore sediment transport on a sandy shoreface, Tibjak Beach, Canadian Beaufort Sea. Mar. Geol., 113: 283-304.

Komar, P.D. and M.C. Miller. 1975. On the comparison between the threshold of sediment motion under waves and unidirectional currents with a discussion of the practical evaluation of the threshold. J. Sediment. Petrol., 45: 362-367.

Larson, M. and N.C. Kraus. 1995. Prediction of crossshore sediment transport at different spatial and temporal scales. Mar. Geol., 126: 111-127.

Layton, J. 1990. Basin Geometry. In: P. Bruun (ed.). Port Engineering Vol. 2: Harbor Transportation, Fishing Ports, Sediment Transport, Geomorphology, Inlets and Dredging. Gulf Publishing Company, Houston, pp. 486-490.

Le Roux, J.P. 1994a. Net sediment transport patterns inferred from grain-size trends, based upon definition of "transport vectors"-comment. Sediment. Geol., 90: 153-156.

Le Roux, J.P. 1994b. An alternative approach to the identification of net sediment transport paths based on grain-size trends. Sediment. Geol., 94: 97-107.

Le Roux, J.P., R.D. O'Brien, F. Rios and M. Cisternas. (in press). Analysis of sediment transport paths from grain-size parameters. Comput. Geosci.

Lewis, D.W. 1984. Practical Sedimentology. Hutchinson Ross Publishing Company, Stroudsburg, Pennsylvania, 229 pp.

Li, M.Z. and C.L. Amos. 2001. SEDTRANS 96: the upgraded and better calibrated sediment-transport model for continental shelves. Comput. Geosci., 27: 619-645.

Masselink, G. 1992. Longshore variation of grain size distributions along the coast of the Rhone delta, Southern France: A test of the "McLaren model". J. Coast. Res., 8: 286-291.

McCave, I.N. 1978. Grain-size trends and transport along beaches: an example from eastern England. Mar. Geol., 28: M43-M51.

McLaren, P. 1981. An interpretation of trends in grainsize measures. J. Sediment. Petrol., 51: 611-624.

McLaren, P. and D. Bowles. 1985. The effects of sediment transport on grain-size distributions. J. Sediment. Petrol., 55: 457-470. 
McLaren, P. and D.I. Little. 1987. The effects of sediment transport on contaminant dispersal: An example from Milford Haven. Mar. Pollut. Bull., 18(11): 586-594.

McLaren, P., W.J. Cretney and R.I. Powys. 1993. Sediment pathways in a British Columbia Fjord and their relationship with particle-associated contaminants. J. Coast. Res., 9: 1026-1043.

McManus, J. 1988. Grain size determination and interpretation. In: M. Tucker (ed.). Techniques in Sedimentology. Blackwell, Oxford, pp 63-85.

Pedreros, R., H.L. Howa and D. Michel. 1996. Application of grain size trend analysis for the determination of sediment transport pathways in intertidal areas. Mar. Geol., 135: 35-49.

Pettijohn, F.G. and J.D. Ridge. 1932. A textural variation series of beach sands from Cedar Point, Ohio. J. Sediment. Petrol., 2: 76-88.

Pettijohn, F.G., P.E. Potter and R. Siever. 1972. Sand and Sandstone. Springer-Verlag, New York, 618 pp.

Pineda, V., A. Cecioni and S. Collao. 1988. Características sedimentológicas y mineralógicas de la bahía de Concepción. In: V Congreso Geológico Chileno, Tomo II, pp. C295-C309.

Pond, S. and G. L. Pickard. 1978. Introductory dynamic oceanography. Pergamon Press, Oxford, $241 \mathrm{pp}$.

Saavedra, N. 1980. La presión y la dirección del vien- to en Concepción. Tralka, 1: 153-162.

Saville, T. Jr. 1954. The effect of fetch width on wave generation. U.S. Army Corps of Engineers, Beach Erosion Board, Tech. Mem., 70 pp.

Smith, J.M. 1991. Wind-wave generation on restricted fetches. Department of the Army, Waterways Experiment Station, Corps of Engineers, Coastal Eng. Res. Cent., Vicksburg, Miscellaneous Paper CERC-91-2, 25 pp.

Sobarzo, M. 1993. Caracterización de la circulación de bahía Concepción, Chile: Un análisis temporal $\mathrm{y}$ en el dominio de la frecuencia. Tesis de Magister, Universidad de Concepcion, Concepción, 128 pp.

Sobarzo, M.B., D. Figueroa and D.R. Arcos. 1997. The influence of winds and tides in the formation of circulation layers in a bay, a case study: Concepción Bay, Chile. Estuar. Coast. Shelf Sci., 45: 729-736.

Soulsby, R.L. 1997. Dynamics of marine sands. Thomas Telford Publications, London, 249 pp.

Syvitski, J.P.M., K.W. Asprey and D.A. Clattenburg. 1991. Principles, design and calibration of settling tubes. In: J.P.M. Syvitski (ed.). Principles, Methods and Application of Particle Size Analysis. Cambridge University Press, New York, pp. 45-63.

Watson, G.S. 1966. The statistics of orientation data. J. Geol., 74 (2): 786-797. 